\title{
Effects of Glucocorticoid-Treatment and/or Adrenalectomy on the Changes of Plasma Glucose and NEFA Levels after Insulin Injection in Sheep
}

\author{
Yoshiyuki Sasaki, Kazuyuki Moriya and Hisashi Hamada \\ College of Agriculture, Kyoto University Kyoto-shi 606
}

(Received December 22, 1980)

\begin{abstract}
To investigate roles of glucocorticoids in insulin tolerance in ruminants, this study was carried out using the intact and glucocorticoid-treated and/or adrenalectomized (ADX) sheep. Experiment 1: Ascending graded doses of insulin (0.05, 0.1, 0.2 and $0.4 \mathrm{IU} / \mathrm{kgBW}$ ) were injected intravenously into two $\mathrm{ADX}$ sheep weekly to determine the dosage of insulin necessary to induce hypoglycemic signs. Experiment 2: Five treatments were involved in Experiment 2. Saline and insulin were injected intravenously in Treatment 1 and 2, respectively. The sheep in both treatments were intact. In Treatment 3, insulin was injected into the ADX animals. In Treatment 4 and 5 , insulin was injected into the ADX animals after preglucocorticoid-treatment $(25 \mathrm{mg} / \mathrm{head} /$ day and $50 \mathrm{mg} / \mathrm{head} / \mathrm{day}$, respectively, for three consecutive days). The insulin dosage was always $0.4 \mathrm{IU} / \mathrm{kgBW}$. The changes of plasma glucose and non-esterified fatty acid (NEFA) levels were then surveyed. In Experiment 1, one animal showed hypoglycemic signs at $0.1 \mathrm{IU} / \mathrm{kgBW}$ of insulin and the other at $0.4 \mathrm{IU} / \mathrm{kgBW}$. In Experiment 2, all animals in Treatment 3 showed hypoglycemic signs. In Treatment 2, 4 and 5 , no animal showed any hypoglycemic signs, though the plasma glucose level decreased to nearly $20 \mathrm{mg} / \mathrm{d} l$. On the other hand, the plasma NEFA level in Treatment 2 rapidly increased to about $900 \mu \mathrm{eq} / l$ within two hours after the insulin injection and the maximum level was nine times as high as the initial level. In Treatment 3 , however, the plasma NEFA level did not remarkably increase. Though no hypoglycemic signs appeared in Treatment 4 and 5 , the plasma NEFA levels were still about $500 \mu \mathrm{eq} / l$, which were not significantly different from that in Treatment 3 . In this study, it was confirmed in sheep that the insulin tolerance which had been lost by adrenalectomy was restored by preglucocorticoid-treatment. From these facts, it is suggested that glucocorticoid plays an important role in the underlying mechanism in ruminant insulin tolerance.
\end{abstract}

Jpn. I. Zootech. Sci., 52 (11): 780-788, 1981

It is well established that ruminants do not show any hypoglycemic signs with a high dosage of insulin, namely, convulsive activity, muscular spasmus, ataxia and inability to stand ${ }^{1)}$. That is, they have insulin tolerance ${ }^{1-5)}$. Ruminants acquire insulin tolerance as their rumina develop ${ }^{3,5)}$. This suggests that the insulin tolerance in ruminants is accompanied by unique aspects of glucose metabolism.

From the above stated point of view, reasons for the insulin tolerance could be listed as follows; 1) an antagonistic hormone to insulin may have more important role with respect to the control of the plasma glucose level in ruminants than in nonruminants, 2) ruminants may have more rational mechanism for saving glucose, that is, non-esterified fatty acid (NEFA), keton bodies etc. may be more efficiently utilized 
as energy sources in place of glucose than in nonruminants, 3) target tissues of ruminants may be less sensitive to insulin than those of nonruminants.

In fact, a certain level of about 70 percent of the normal level of plasma glucose was maintained under fasting conditions of more than 30 days in sheep ${ }^{6}$. However, adrenalectomized (ADX) sheep were not able to maintain the plasma glucose level for only 1 to 14 days $^{7,8)}$. On the other hand, glucocorticoid-treated ADX sheep endured fasting as well as the intact animals ${ }^{7,8}$. From these points, it was suggested that glucocorticoid was an essential factor for ruminants to maintain the plasma glucose level under fasting.

On the other hand, glucocorticoids have antagonistic effects to insulini,10). Glucocorticoids inhibit glucose utilization in peripheral tissues and promote gluconeogenesis by way of activating gluconeogenic key enzymes ${ }^{13,14}$. Therefore, the role of glucocorticoids is of interest in conection with supporting insulin tolerance in ruminants.

The present objective is to reveal the role of glucocorticoids in the underlying mechanism in insulin tolerance in ruminants. Using the intact and glucocorticoidtreated and/or ADX sheep, changes of plasma glucose and NEFA levels after insulin injection were surveyed.

\section{Materials and Methods}

Fifteen Japanese Corriedale wethers weighing $45 \pm 4.8 \mathrm{~kg}$ (mean \pm S. D.) were used. Nine of them were adrenalectomized by the modified method of Buck and BOND $^{7,15)}$. These animals were tested for adrenal gland residue by their palsma cortisol level, determined by radioimmunoassay ${ }^{16)}$, and its response to ACTH. The plasma cortisol level was very low $(0.28-2.75 \mathrm{ng} / \mathrm{ml})$, and did not respond to ACTH except for one animal whose plasma cortisol level increased only two times. Deoxycorticosterone acetate (DOCA) ( $5 \mathrm{mg} / \mathrm{head} /$ day) was administered intramuscularly to ADX sheep every day in order to maintain normal metabolism of electrolytes and water.

The daily ration of each animal consisted of legumes hay, $600 \mathrm{~g}$ per head, and concentrate of $1.2 \%$ of body weight (alfalfa meal, 6 parts; wheat bran, 5 parts; soybean meal 1 part; $\mathrm{DCP}=16.3 \%, \mathrm{TDN}=61.2 \%$ ).

Preglucocorticoid-treatment: The 17-hydroxycorticosterone-21-acetate (HCA; HYDROCORTONE ACETATE, BANYU PHARMACEUTICAL CO., LTD. Japan) was injected into the buttock muscle once a day for three consecutive days prior to the insulin injection.

Experiment 1: Ascending graded doses of insulin (ISUZILIN, 'shimizu', SHIMIZU PHARMACEUTICAL CO., LTD. Japan; $0.05,0.1,0.2$ and $0.4 \mathrm{IU} / \mathrm{kgBW}$ ) were injected intravenously into two ADX sheep to determine the dosage of insulin necessary to induce hypoglycemic signs. If ADX sheep showed hypoglycemic signs at a certain dose of insulin, the dosage was not increased the next week, but the same dosage was injected again with the preglucocorticoid-treatment for three days.

Experiment 2: The five treatments summarized in Table 1 were carried out. Group A, which consisted of three sheep, was used repeatedly before and after adre- 
SASAKI, Moriya and Hamada

Table 1. Experimental design (Experiment 2)

\begin{tabular}{|c|c|c|c|c|c|}
\hline \multirow{2}{*}{ Treatment } & \multirow{2}{*}{ Adrenal glands } & \multirow{2}{*}{$\begin{array}{c}\text { Insulin }{ }^{\mathbf{a}} \\
(\mathrm{IU} / \mathbf{k g ~ B W})\end{array}$} & \multirow[b]{2}{*}{ Trial $1^{c}$} & \multirow{2}{*}{$\frac{\text { Trials }}{\text { Trial } 2^{\text {b) }}}$} & \multirow[b]{2}{*}{ Others } \\
\hline & & & & & \\
\hline 1 & Intact & $\mathrm{O}^{\mathrm{b}\}}$ & $A(2)$ & 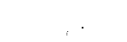 & $\mathrm{D}(2)$ \\
\hline 2 & Intact & 0.4 & $A(2)$ & $B(1)$ & $\mathrm{B}(1), \mathrm{D}(2)$ \\
\hline 3 & ADX & 0.4 & $A(1)$ & $A(1)$ & $E(1)$ \\
\hline 4 & $\mathrm{GC}(25)$-treated-ADX & 0.4 & $A(1)$ & $C(1)$ & $C(1)$ \\
\hline 5 & $\mathrm{GC}(50)$-treated-ADX & 0.4 & $A(1)$ & & \\
\hline
\end{tabular}

a) Insulin was injected intravenously. b) Saline was injected intravenously in the same amount as insulin. c) Group A was used for each treatment on different days. d) The different groups (B, A and $\mathrm{C}$ ) which consisted of animals with different conditions were used for Treatment 2,3 and 4 , respectively, on the same day. The number of animals in Groups A, B, C and D are three, but that of $E$ is one. The number of repeats is shown in parentheses. Abbreviations are used as follows; ADX: adrenalectomy, GC (25) and GC (50): preglucocorticoid-treatment (HCA, 25 and $50 \mathrm{mg} / \mathrm{head} / \mathrm{day}$ for three consecutive days, i. m., respectively).

nalectomy as Trial 1. Here, responses to the various treatments were compared using the same animal group on different days. On the other hand, Groups B, A and C were used for comparison against Treatment 2, 3 and 4, respectively as Trial 2. Furthermore, some other experiments were done using Groups B, C, D and E.

Blood samples were taken at $0,1 / 3,2 / 3,1,2,4,6$ and 8 hours after the insulin injection from the jugular vein with heparinized syringes. Plasma was separated by centrifugation and stored at $-20^{\circ} \mathrm{C}$ until assayed. Animals were not fed during the experiments, but allowed free access to water.

Chemical analysis: The plasma glucose level was determined by the assay kit (ORTODIN-B eiken, EIKEN CHEMICAL CO., LTD. Japan), based on the method of DuBowsKr ${ }^{17}$ ). The plasma NEFA level was determined by the modified method of MAEHATA and NAKA ${ }^{18,19}$. The following modifications were done in terms of extractive procedures for plasma NEFA: $2 \mathrm{ml}$ iso-propanol and $n$-heptane mixture (iso-propanol $75 \%(\mathrm{v} / \mathrm{v}), n$-heptane $25 \%(\mathrm{v} / \mathrm{v})]$ were used for the first extraction, and the second extraction was done three times with $1 \mathrm{ml}$ of $n$-heptane.

Statistical analysis: Several indices have been used to compare the intensity of the response of plasma glucose and NEFA levels to the insulin test ${ }^{20,21)}$. In this study, the maximum per cent decrease and minimum level for plasma glucose (GDCR, Gmin, respectively), he maximum and minimum levels for plasma NEFA (NEFAmax, NEFAmin, respectively) were calculated and analyzed. GDCR was calculated as follows:

$$
\operatorname{GDCR}(\%)=\left[\left(\mathrm{G}_{0}-\mathrm{G}_{\mathrm{min}}\right) / \mathrm{G}_{0}\right] \times 100
$$

where $G_{0}$ is the initial level of plasma glucose. The analysis of variance was done with LSML 76 written by HARveY which was a program for least-squares analysis of variance $^{22,23)}$. FACOM M-200 in Data Processing Center Kyoto University was used for calculation. 

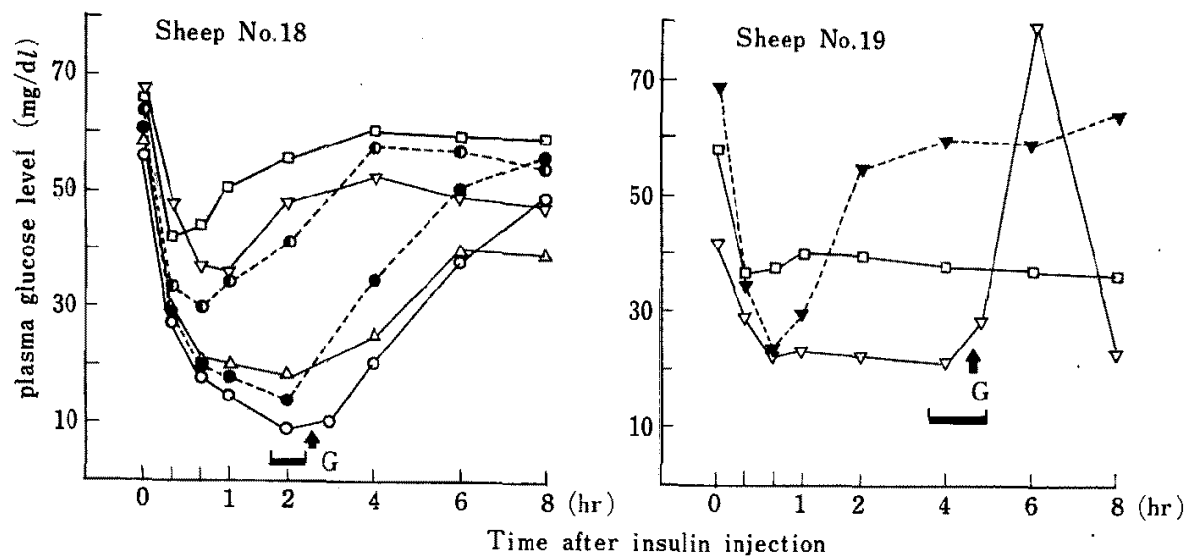

Fig. 1. Changes of plasma glucose level after ascending graded doses of insulin injection. The doses of insulin were $0.05 \mathrm{IU} / \mathrm{kgBW}(\square-\square) ; 0.1 \mathrm{IU} / \mathrm{kgBW}(\nabla-\nabla) ; 0.2 \mathrm{IU} / \mathrm{kgBW}(\Delta-\Delta)$; and $0.4 \mathrm{IU} / \mathrm{kgBW}(0-0) . \bullet \cdots \cdot \bullet$ and $\nabla \cdots \cdot$ show the changes of plasma glucose level after insulin injection (0.4 IU $/ \mathrm{kgBW}$ for No. 18 and $0.1 \mathrm{IU} / \mathrm{kgBW}$ for No. 19) with preglucocorticoidtreatment $(12.5 \mathrm{mg} / \mathrm{head} / \mathrm{day})$. $\cdots$. shows the changes after insulin injection $(0.4 \mathrm{IU} / \mathrm{kgBW})$ with preglucocorticoid-treatment $(25 \mathrm{mg} / \mathrm{head} /$ day $)$. Arrow with $\mathrm{G}$ means the time when glucose was injected intravenously. The dose were $5,8 \mathrm{~g}$ in No, 18 and $14 \mathrm{~g}$ in No. 19. س: shows period during which hypoglycemic signs were observed.

\section{Results}

Experiment 1: Fig. 1 shows the changes in the plasma glucose level after each dose of insulin in two ADX sheep. The higher the dosage was, the larger the decrease of the plasma glucose level. One sheep (No. 18) showed hypoglycemic signs at $0.4 \mathrm{IU} / \mathrm{kgBW}$ and the other (No. 19) at $0.1 \mathrm{IU} / \mathrm{kgBW}$. After the preglucocorticoidtreatment $(12.5 \mathrm{mg} /$ head/day), hypoglycemic signs were not observed in No. 19, despite the same dosage of insulin $(0.1 \mathrm{IU} / \mathrm{kgBW})$. However, No. 18 showed slight hypoglycemic signs with the preglucocorticoid-treatment. When two times of the previous dosage of glucocorticoid ( $25 \mathrm{mg} /$ head/day) was injected in the following week, No. 18 did not show any hypoglycemic signs with the same dosage of insulin (0. $4 \mathrm{IU} / \mathrm{kgBW})$.

Experiment 2: The changes in the plasma glucose level after the insulin injection in Trial 1 are as shown in Fig. 2. In Treatment 1, the plasma glucose level remained unchanged throughout the experiment, whereas, in Treatment 2 , the level rapidly decreased after the insulin injection and reached $23.4 \pm 2.7 \mathrm{mg} / \mathrm{d} l$ (mean $\pm \mathrm{S} . \mathrm{D} ., \mathrm{n}=6$ ) $60 \mathrm{~min}$. later without showing any hypoglycemic signs. Then the level returned to the initial level within 4 or 6 hours after insulin injection.

On the other hand, in Treatment 3, at $60 \mathrm{~min}$. after the insulin injection, the plasma glucose level decreased dramatically and was closer to $10 \mathrm{mg} / \mathrm{d} l$ which was the lowest level in this experiment. After that, all animals showed hypoglycemic signs within 2 hours. As these animals were not able to recover from hypoglycemic signs by themselves, glucose ( $8 \mathrm{~g} /$ head, i.v.) was administered. One animal recovered completely by this treatment, but the others still showed hypoglycemic signs 1-2 hours 


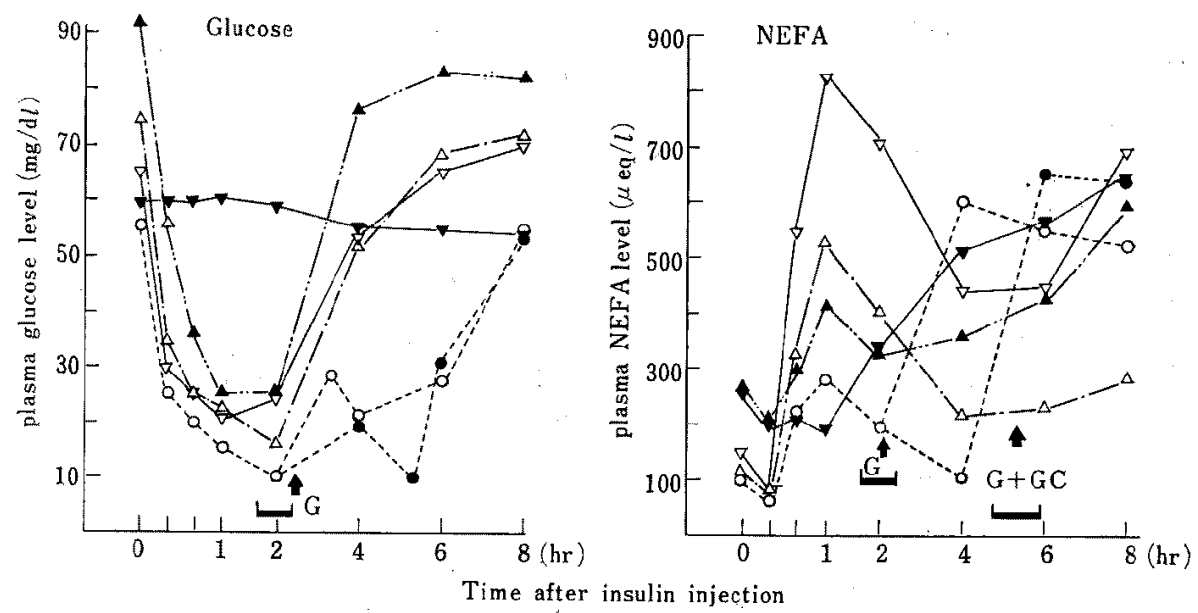

Fig. 2. Changes of plasma glucose and NEFA levels after insulin injection in Trial 1 of Experiment 2. Each point represents mean of six observations duplicaed with three animals in Treatment 1,2 and 3 , and three observations in Treatment 4 and 5 , where; $\mathbf{\nabla}-\boldsymbol{\nabla}$ shows Treatment $1, \nabla-\nabla$; Treatment $2,0 \cdots 0$; Treatment $3, \Delta--\Delta$; Treatment $4, \mathbf{\Delta}-\cdots-\Delta$; Treatment 5. -..- shows changes of plasma glucose and NEFA levels of five animals in Treatment 3 which showed hypoglycemic signs again, after first glucose injection. Arrow with $G$ means the time when glucose $(8 \mathrm{~g} /$ head $)$ was injected intravenously. Arrow with $\mathrm{GC}$ means the time when HCA as glucocorticoid was injected $(2 \mathrm{mg} / \mathrm{kgBW}$, i. p.). - لـ shows period during which hypoglycemic signs were observed.

after the glucose injection, so HCA ( $2 \mathrm{mg} / \mathrm{kgBW}$, i. p.) and/or glucose $(8 \mathrm{~g} / \mathrm{head}$, i. v.) were injected. With these treatments, these animals also recovered from hypoglycemic signs and their glucose levels returned to the initial level. On the other hand, the changes in the plasma glucose level in Treatment 4 and 5 were similar to those in Treatment 2 and no animal in these treatments showed any hypoglycemic signs.

As the changes the in the plasma glucose level after the insulin injection in Trial 2 were nearly the same as in Trial 1, the figures are not given here.

Table 2. Least-squares analysis of variance for minimum level and maximum per cent decrease of plasma glucose

\begin{tabular}{lrcc}
\hline $\begin{array}{c}\text { Source } \\
\text { of } \\
\text { Variance }\end{array}$ & d.f. & \multicolumn{2}{c}{ Mean squares } \\
\cline { 3 - 4 } & & $\mathrm{G}_{\min ^{2}}{ }^{\text {a }}$ & $\mathrm{G}_{\mathrm{DCR}}{ }^{\text {b3 }}$ \\
\hline Treatment & 4 & $2631.1^{* *}$ & $7220.7^{* *}$ \\
Individual & 12 & 31.1 & 37.9 \\
Error & 32 & 36.0 & 42.3
\end{tabular}

**; $\mathrm{P}<.01$. a) $\mathrm{G}_{\mathrm{min}}$ is an abbreviation of minimum plasma glucose level. b) $G_{D C R}$ is an $a b$ breviation of maximum per cent decrease of plasm glucose. All data taken from Experiment 2 were analyzed. 
Insulin Tolerance and Cortisol in Sheep

Table 3. Least-squares means for minimum level and maximum per cent decrease of plasma glucose and minimum and maximum of plasma NEFA levels

\begin{tabular}{|c|c|c|c|c|}
\hline \multirow{3}{*}{ Treatment } & \multicolumn{4}{|c|}{ Least-squares mean } \\
\hline & \multicolumn{2}{|c|}{ Glucose } & \multicolumn{2}{|c|}{ NEFA } \\
\hline & $\mathrm{G}_{\min }(\mathrm{mg} / \mathrm{d} l)$ & $\mathrm{G}_{\mathrm{DCR}}(\%)$ & $\overline{N E F A_{\min }(\mu e q / l)}$ & $\mathrm{NEFA}_{\max }(\mu \mathrm{eq} / l)$ \\
\hline 1 & $56.8^{2}$ & $7.0^{\mathrm{a}}$ & $217.0^{\mathrm{a}}$ & $295.6^{\mathrm{a}}$ \\
\hline 2 & $23.0^{\circ}$ & $62.4^{b}$ & $115.8^{\mathrm{b}}$ & $1040.0^{c}$ \\
\hline 3 & $10.9^{c}$ & $80.5^{c}$ & $98.8^{b}$ & $349.3^{\mathrm{ab}}$ \\
\hline 4 & 19. $7^{\mathrm{bc}}$ & $72.6^{\mathrm{b}}$ & $86.7^{b}$ & $595.9^{b}$ \\
\hline 5 & $24.8^{b}$ & $70.1^{b}$ & $206.6^{\mathrm{ab}}$ & $512.8^{b}$ \\
\hline
\end{tabular}

$a, b, c$; Means within column with different superscrips are significantly different $(P<.05)$. Abbreviations are used as follows; $G_{\min }$ : minimum plasma glucose level, $\mathrm{G}_{D C R}$ : maximum per cent decrease of plasma glucose, $N E F A_{\min }$ : minimum plasma NEFA level, NEFA $A_{\max }$ : maximum plasma NEFA level. The details of each tretment are explained in Table 1.

The significance of the effect of the repeat was tested preliminarily using the data obtained repeatedly from the same group (Table 1). The effect was not significant. Therefore, all data were used for the following statistical analysis ignoring the date when the treatment was carried out.

Table 2 shows the result of least-squares analysis of variance for two indices, GDCR and $\mathrm{G}_{\mathrm{min}}$. Effects of the treatments on both indices were significant $(\mathrm{P}<.01)$. The least-squares means for the treatments are shown in Table 3. In terms of both indices, Treatment 3 was significantly lower than Treatment 1 . Treatment 3 was lower than Treatment 2, while Treatment 4 and 5 were not different from Treatment 2.

Changes of the plasma NEFA level after the insulin injection in Trial 1 are as shown in Fig. 2. In Treatment 2, the plasma NEFA level decreased to about $100 \mu \mathrm{eq} / l$ just after the insulin injection, but the level rapidly increased and reached the maximum level which was $883 \pm 332 \mu \mathrm{eq} / l$ (mean $\pm S . D ., n=6$ ). Then, the plasma NEFA leve] decreased and became nearly equal to the level of Treatment 1,4 hours after the insulin injection. After that, the changes in the plasma NEFA level in Treatment 2 were similar to that in Treatment 1 throughout the experiment.

In Treatment 3, 4 and 5, the plasma NEFA level decreased just after the insulin injection as well as in Treatment 2. However, the later changes in the plasma NEFA level were different from Treatment 2. In Treatment 3, the plasma NEFA level did not remarkably increase and was only about $200 \mu \mathrm{eq} / l$ even when hypoglycemic signs appeared. The changes in the plasma NEFA level in Treatment 4 and 5 were almost the same as in Treatment 3, except that the increase in the former was somewhat larger than in the latter. In addition, the magnitude of increase was not different between Treatment 4 and 5 .

The changes of the plasma NEFA level after the insulin injection in Trial 2 were nearly the same as in Trial 1.

The least-squares analysis of variance for NEFAmax and NEFAmin is as shown 


\section{Sasaki, Moriya and Hamada}

Table 4. Least-squares analysis of variance for $\mathrm{mi}$ nimum and maximum plasma NEFA levels

\begin{tabular}{lrcc}
\hline $\begin{array}{c}\text { Source } \\
\text { of } \\
\text { Variance }\end{array}$ & d.f. & \multicolumn{2}{c}{ Mean squares } \\
\cline { 3 - 4 } & NEFA $_{\min }{ }^{2}$ & NEFA $_{\max }{ }^{\text {b) }}$ \\
\hline Treatment & 4 & $26079.5^{*}$ & $935427.9 * *$ \\
Individual & 12 & 5128.3 & $186564.1^{* *}$ \\
Error & 32 & 8125.1 & 60998.8
\end{tabular}

$* ; \mathrm{P}<.05, * * ; \mathrm{P}<.01$. a) $\mathrm{NEFA}_{\min }$ is an abbreviation of minimum plasma NEFA level. b) NEFA $A_{\max }$ is an abbreviation of maximum plasma NEFA level. All data taken from Experiment 2 were analyzed.

in Table 4. Effects of the treatment were significant for both NEFAmax $(P<.01)$ and NEFAmin $(P<.05)$. The least-squares means of the treatments are shown in Table 3. NEFAmin was not significantly different among Treatment $2,3,4$ and 5 . On the other hand, NEFAmax in Treatment 2 was significantly higher than in Treatment 1 , but Treatment 3 was significantly lower than Treatment 2 . Treatment 4 and 5 were significantly lower than Treatment 2 .

\section{Discussion}

No hypoglycemic sign appeared in sheep even when a high dosage of insulin (5-10 IU/kgBW) was injected intravenously ${ }^{1-5)}$. As described in the results, however, all ADX sheep showed hypoglycemic signs with a $0.4 \mathrm{IU} / \mathrm{kgBW}$ insulin injection and they could not regain consciousness by themselves. These results indicate that the insulin tolerance in sheep is lost by adrenalectomy. On the other hand, a glucocorticoid-treated ADX sheep did not show hypoglycemic signs even with an insulin injection of the same amount $(0.4 \mathrm{IU} / \mathrm{kgBW})$. Moreover, the plasma glucose level of the $\mathrm{ADX}$ sheep varied from time to time as those of the intact sheep. Therefore, ruminant insulin tolerance seems to be due to the action of glucocorticoid.

On the other hand, CRYER et al. reported that changes in the plasma glucose level after insulin injection in ADX human subjects were not different from those in normal human subjects ${ }^{2425)}$. They suggested that adrenal cortical hormones were not necessary to restore the plasma glucose level after an insulin injection in the case of human subjects ${ }^{24-27}$.

From these points, the difference in the insulin tolerance between ruminants and nonruminants may be explained in terms of a differential action of glucocorticoids. The sorts of glucocorticoid actions related to insulin tolerance are discussed below with respect to reasons for insulin tolerance in ruminants.

In general, glucocorticoids are antagonistic to insulin in relation to the control of plasma glucose level,10). It is known that the plasma cortisol level increases in sheep after an insulin injection. However, the same response is also observed in nonruminants ${ }^{24,27,29)}$. There seems to be no difference in this point between ruminants and nonruminants. 
RANDLE et al. proposed the glucose-fatty acid cycle theory, that is, the plasma NEFA level increases and fatty acid oxidation is promoted in muscles when the plasma glucose decreases. Thus, utilization of glucose becomes diminished and glucose will be preserved ${ }^{30)}$. The same mechanism of glucose-fatty acid cycle seems also to be present in sheep ${ }^{41}$.

The plasma NEFA level markedly increased with a decrease of plasma glucose level after the insulin injection in the intact sheep and decreased following restoration of the glucose level. This result suggests that utilization of NEFA is accelerated after administration of insulin. Moreover, no increase in the plasma NEFA level was observed in the ADX sheep. This fact is very interesting in terms of the roles of glucocorticoid in insulin tolerance. In the glucocorticoid-treated ADX sheep, however, the plasma NEFA level did not increase after the insulin injection although they did not show any hypoglycemic signs. Therefore, it seems to be difficult to explain roles of glucocorticoid in insulin tolerance from the point of the glucose-fatty acid cycle theory.

Moreover, it was reported in rats that sensitivity of target tissues to insulin was decreased by glucocorticoids ${ }^{31}$. Such reports on ruminants are not available. So, it will be necessary to investigate the action of glucocorticoids to the sensitivity of target tissues in ruminants.

In conclusion, it is suggested that glucocorticoid is an important factor to support insulin tolerance in ruminants. However, a further investigation is necessary to clarify the roles of glucocorticoids in the mechanism underlying insulin tolerance in ruminants.

\section{References}

1) Reid, R. L., Aust. J. Agr. Res., 2: 146-157. 1951.

2) Reid, R. L., Aust. J. Agr. Res., 2: 132-145. 1951.

3) Jarketr, I. G. and B.J. Potrer, Aust. J. Exp. Biol. Med. Sci., 31: 311-318. 1953.

4) Annison, E. F., Aust. J. Agr. Res., 11: 58-64. 1961.

5) Ballard, F. J., R. W. Hanson and D. S. Kronfeld, Fed. Proc., 28: 218-231. 1969.

6) SAsaki, Y., K. KumazAKI and O. IKedA, Jpn. J. Zootech. Sci., 45: 81-87. 1974.

7) Hamada, H., M.S. thesis research report. Kyoto Univ., Kyoto, Japan. 1979.

8) Sasaki, Y., Proc. Jap. Soci. Anim. Nutri. Metab., 24: 142-165. 1980.

9) Levine, R., Diabetes., 13: 362-365. 1964.

10) Perley, M. and D. M. Kipnis, New. Engl. J. Med., 274: 1237-1241. 1966.

11) Bassett, J. M., S. C. Mil.s and R. L. Reid, Metabolism., 15: 922-932. 1966.

12) Glenn, E. M., B. J. Bowman., R. B. Bayer and C. E. Meyer, Endocrinol. 68: 386-410. 1961.

13) TePperman, J., METABOLIC AND ENDOCRINE PHYSIOLGY. $3 \mathrm{rd}$ ed. 122-151. YEAR BOOK MEDICAL PUBLISHERS. U.S. A. 1973.

14) Ray, P. D., D. O. Foster, and H. A. LARdy, J. Biol. Chem., 239: 3396-3400. 1964.

15) Buck, W. B. and K. Bond, Am. J. Vet. Res., 27: 155-160. 1966.

16) Makino, T. and A. Kanbegawa., Folia. Endocrinol. Jap., 49: 1297-1305. 1973.

17) Duвowsкi, K. M., Clin. Chem., 8: 215-235. 1962.

18) Maehata, E. and T. Naka, Rinsho Kagaku., 1: 447-456. 1972.

19) Maruyama, S., M.S. thesis research report. Kyoto Univ. Kyoto. Japan. 1978.

20) Greenwood, F. C., J. Landom and T. C. B. Stamp, J. Clin. Invest., 45: 429-436. 1966.

21) Leistio, S. and J. Perheentupa, Acta. Endocrinol., 88: 99-112. 1978. 


\title{
SASAki, Moriya and Hamada
}

22) Harvey, W. R., Least-squares Analysis of Data with Unequal Subclass Numbers. A.R.S., 20-8. U. S. D. A. 1960.

23) Harvey, W.R., User s Guide for LSML 76. Mixed Model Least-squares and Maximum Likelihood Computer Program. Mimeo. Ohio. State. Univ. Columbus. 1977.

24) Gerich, J., J. Dayis, M. Lorenzi, R. Rizza, N. Bohannon, J. Karam, S. Lewis, R. Karlan, T. Schultz and P. Cryer, Am. J. Physiol., 236: E 380-E 385. 1979.

25) Gerich, J., P. CRYER and R. RizzA, Metabolism., 29: 1164-1175, 1980.

26) Rizza, R.A., P. E. Cryer and J. E. Gerich, J. Clin. Invest., 64: 62-71. 1979.

27) Garber, A. J., P. E. Cryer, J. V. Santiago, M. W. Haymond, A. S. Pagliara and D. M. Kipnis, J. Clin. Invest., 58: 7-15. 1976.

28) Doozey. P.C. and V. J. Wrlliams, Aust. J. Biol. Sci., 28: 503-509. 1975.

29) Landn, J., V. Wynn and V. H.T. James, J. Endocrinol 27: 183-192. 1963.

30) Randee, P. J., P. B. Garlans, C. H. Hales and C. N. Newsholm, Lancet., 1：785-789. 1963.

31) Olefisky, J. M., J. Johnson, F. Liu, P. Jen and G. M. Reaven, Metabolism., 24 517-527. 1975.

\section{ヒツジにおけるインシュリン投与後の血漿中糖又び NEFA 濃度とグルココルチコイドとの関連性}

\author{
佐々木義之・守屋和幸・浜田 久 \\ 京都大学農学部, 京都市 606
}

\begin{abstract}
反罚動物に特有なインシニリン耐性機綪におけるダル ココルチコイドの役割について，正常および副餐摘出七 ッジを用いて検討を行った。すず副腎摘出ヒッジ 2 頭を 用い, 1 週間間隔でインシュリンを $0.05,0.1,0.2,0.4$ $\mathrm{IU} / \mathrm{kgBW}$ と倍増しながら副腎摘出ヒッジに括ける低血 糖症状の発現に必要なインシュリン量について 調べた (実験 I). 次に 5 処理区 (以下カッュ内に副腎の状態, コルチゾール投与量 $(\mathrm{mg} /$ 頭/日)，インシュリン投与量

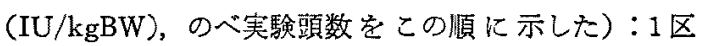
(正常，0，0，12 頭)，2区 (正常，0，0.4，18 頭)，3区 (摘出， $0,0.4,7$ 頭)，4区 (摘出，25，0.4，6 䫫)， 5 区(摘出，50，0.4，3頭）を設け，インシニリン投与後の 血糖值及び，血脽中 NEFA 濃度の変化定調べた（实験 II).
\end{abstract}

実験 I では，1頭は $0.11 \mathrm{UU} / \mathrm{kgBW}$ のインシュリン投 与で，安た，他の 1 頭は $0.4 \mathrm{IU} / \mathrm{kgBW}$ の投与によって 各々低血糖症状を呈した。 また実験 II です処理 3 区で
はすべての個体が低血糖症状を呈した，処理 2 区及びュ ルテゾール処理を施した処理 4 及び 5 区では血糖值は $20 \mathrm{mg} / d l$ 前後にまで低下したが 低血糖症状は示さなか った. 一方, 血獎中 NEFA 濃度は処理 2 区ではインシ ニリン投与後約 $900 \mu \mathrm{eq} / \mathrm{l}$ と投与前の 9 倍近くに上昇し たが，処理 3区では殆えど上昇沬認められなかった。糖 一方，処理 4 区及び 5 区で悢血糖症状汢発現せず，血 糖值の変化法处理 2 区之ほ济同じですったにもかかわ らずインシュリン投与後の血獎中 NEFA 濃度の上昇 は $500 \mu \mathrm{eq} / l$ と処理 3 区に比べ有意な差恃認められなか った.

以上の結果, グルココルチコイド処理注副腎摘出によ り失なわれたヒッジのインシニリン耐性を回復させるこ とが判明し，このホルモンがインシニリン耐性機構にお ける重要な1因子であることが推察された。

日蓄会報，52(11)：780-788，1981 